\title{
PERILAKU BULLYING DAN KARAKTER REMAJA SERTA KAITANNYA DENGAN KARAKTERISTIK KELUARGA DAN PEER GROUP
}

\author{
Karina ${ }^{1}$, Dwi Hastuti ${ }^{1 *}$, Alfiasari ${ }^{1}$ \\ ${ }^{1}$ Departemen IImu Keluarga dan Konsumen, Fakultas Ekologi Manusia, Institut Pertanian Bogor, \\ Bogor 16680, Indonesia \\ *)E-mail: tutimartianto@yahoo.com
}

\begin{abstract}
Abstrak
Tujuan dari penelitian ini adalah untuk menganalisis hubungan antara karakteristik keluarga, peer group, karakter (hormat santun dan empati), dan perilaku bullying pada remaja di Kota Bogor. penelitian ini juga bertujuan untuk menganalisis perbedaan antara keterikatan dengan peer group, peran perilaku bullying, dan karakter berdasarkan jenis kelamin dan asal sekolah. Sebanyak 50 siswa perempuan dan 50 siswa laki-laki, berusia 16-18 tahun, dari Sekolah Menengah Kejuruan Negeri dan Swasta dipilih secara acak klaster. Hasil penelitian menunjukkan ada perbedaan yang nyata pada keterikatan dengan peer group antara siswa SMK Swasta dan negeri, tetapi tidak ada perbedaan antara siswa laki-laki dan siswa perempuan. Siswa perempuan memiliki karakter hormat santun yang lebih tinggi dibandingkan dengan siswa laki-laki dan karakter tersebut berbeda nyata. Berdasarkan asal sekolah, tidak terdapat perbedaan karakter (hormat santun dan empati). Remaja perempuan mempunyai skor bullying lebih tinggi dan mereka lebih dominan untuk melakukan bullying verbal. Usia orang tua berhubungan signifikan dengan karakter remaja (hormat santun dan empati). Keterikatan peer group berhubungan signifikan dengan perilaku bullying: semakin terikat dengan peer group, semakin tinggi perilaku bullying yang dilakukan remaja. Hal tersebut menunjukkan bahwa karakter berhubungan signifikan negatif dengan perilaku bullying.
\end{abstract}

Kata kunci: empati, hormat santun, keterikatan, pembantu bullying, pendukung bullying

\section{Bullying and Character Development of Youth and their Relationship with Family Characteristic and Peer Group}

\begin{abstract}
The purpose of this study was to determine the relationship among family characteristic, peer group, character (respectful and empathy), and bullying of youth at Bogor City. This study also aim to analyse the difference of peer group cohesiveness, bullying role, and character based on sex and school group. Fifty female and fifty male students, ages 16-18, from public and private vocational high school were selected by cluster random sampling. Result showed that there was significant difference at peer group cohesiveness between private and public schools, but no difference between male and female students. Female students more respectful than male and it were significantly different. Based on school group, there was no difference on their character. Female students also had higher score of bullying and they dominantly conducted verbal bullying. Ages of parents was significantly related to character of youth (respectful and empathy). Peer group cohesiveness was significantly related to bullying; the more cohessive to their peers, more bullying conducted by youth. It also showed that character were negatively significant related with bullying.
\end{abstract}

Keywords: assisting the bully, cohesiveness, empathy, reinforcing the bully, respectful

\section{PENDAHULUAN}

Kemajuan suatu bangsa ditentukan oleh kualitas sumber daya manusianya. Remaja adalah salah satu sumber daya manusia yang penting dalam pembangunan nasional. Namun, kualitas remaja tersebut sifatnya masih potensial sehingga perlu dibina dan dikembangkan secara terarah dan berkelanjutan agar dapat membawa Indonesia ke masa depan yang lebih baik. Kenyataan yang terjadi di
Indonesia saat ini adalah remaja di Indonesia justru menunjukkan permasalahan yang semakin serius di berbagai bidang, khususnya di bidang sosial, budaya, dan moral. Beberapa permasalahan tersebut diantaranya adalah kenakalan kriminal, pergaulan bebas, asusila, dan juga masalah degradasi moral yang semakin mengkhawatirkan, seperti perilaku kurang menghormati orang lain, tidak jujur, sampai ke usaha menyakiti diri dengan memakai narkoba, mabuk-mabukan, dan bunuh 
diri (Puspitawati, 2009). Kasus lain yang juga sering terjadi di kalangan remaja adalah kasus bullying di sekolah.

Bullying merupakan tipe kekerasan di sekolah yang paling umum terjadi. Penelitian yang dilakukan di berbagai negara menunjukkan bahwa 8 hingga 38 persen siswa menjadi korban bully (McEachern, et al., 2005). Sementara itu, Swearer dan Doll (2001) mengungkapkan angka kejadian bullying di dunia adalah sekitar 10 persen siswa SMP hingga 27 persen siswa SMA dilaporkan sering menjadi korban bully. Di Indonesia sendiri, hasil penelitian Sejiwa tahun 2008 terhadap sekitar 1.200 orang pelajar di Jakarta, Yogyakarta, dan Surabaya menunjukkan angka kejadian bullying di SMA sebesar 67,9 persen dan SMP sebesar 66,1 persen (Sejiwa, 2010).

Olweus (2003) mengungkapkan beberapa karakteristik pelaku bullying, diantaranya adalah memiliki sikap positif terhadap kekerasan, impulsif, ingin mendominasi orang lain dan kurang memiliki rasa empati. Hal yang serupa juga diungkapkan oleh Lickona (2004) yang menyatakan bahwa perilaku bullying dapat timbul akibat dari kurangnya rasa hormat dan empati di antara sesama. Selain itu, Lagerspetz, Bjorqvist dan Peltonen (1988), diacu dalam Chairani (2005) juga menyebutkan dua ciri penting bullying pada pelajar, yaitu bahwa bullying dilakukan bersama-sama oleh sekelompok orang dan terjadi berdasarkan hubungan dalam kelompok. Mengingat penelitian bullying pada remaja dan keterkaitannya dengan karakter belum banyak dilakukan maka perlu dilakukan penelitian mengenai perilaku bullying dan karakter remaja serta hubungannya dengan kelompok peer group. Kota Bogor dipilih menjadi lokasi penelitian mengingat Kota Bogor merupakan daerah penyangga ibukota dengan kehidupan remaja yang cukup beragam. Penelitian dengan membandingkan dua jenis latar belakang sekolah yang berbeda dilakukan dalam penelitian ini untuk melihat perbedaan keragaan jenis sekolah remaja.

Penelitian ini bertujuan untuk mengidentifikasi karakteristik keluarga, karakteristik remaja, dan peer group remaja laki-laki dan perempuan di dua sekolah yang berbeda. Penelitian ini juga bertujuan untuk mengidentifikasi karakter (hormat santun dan empati) dan perilaku bullying pada remaja laki-laki dan perempuan di dua sekolah yang berbeda, serta untuk menganalisis hubungan antara karakteristik keluarga, remaja, dan peer group dengan karakter dan perilaku bullying remaja
Sekolah Menengah Kejuruan (SMK). Selain itu, penelitian ini juga bertujuan untuk menganalisis perbedaan antara keterikatan remaja dengan peer group, peran perilaku bullying, dan karakter berdasarkan jenis kelamin dan asal sekolah (SMK Negeri dan SMK Swasta).

\section{METODE}

Desain penelitian ini adalah crosssectional study yaitu pengambilan data dilakukan dalam satu waktu tertentu. Lokasi penelitian dipilih secara purposive dengan pertimbangan kesediaan sekolah untuk dijadikan tempat penelitian. Sekolah yang dipilih adalah SMK Negeri dan SMK Swasta yang berlokasi di Kota Bogor. Pengambilan data dilaksanakan pada bulan Agustus 2011.

Remaja yang dipilih sebagai contoh dalam penelitian ini adalah siswa kelas XII, dengan pertimbangan bahwa tindakan bullying itu sendiri lebih sering terjadi karena adanya rasa senioritas kakak kelas kepada adik kelasnya. Selain itu, siswa kelas XII merupakan remaja yang berada pada usia remaja akhir, yaitu antara usia 16 hingga 18 tahun. Para remaja ini akan segera memasuki periode kehidupan selanjutnya sebagai individu yang dewasa dan akan terjun langsung di masyarakat sehingga penting untuk diketahui kualitas dari karakternya. Pengambilan contoh dilakukan dari suatu populasi siswa kelas XII pada masing-masing sekolah dengan menggunakan metode cluster random sampling, dimana pengelompokkan dalam pengambilan contoh didasarkan pada perbedaan jenis kelamin. Jumlah remaja yang diambil sebanyak 50 orang pada tiap sekolah, dengan jumlah remaja lakilaki dan perempuan sama besarnya.

Data primer dalam penelitian ini diperoleh dengan metode survei terhadap remaja dengan alat bantu kuesioner self report yang meliputi data karakteristik remaja (usia dan jenis kelamin), karakteristik keluarga (usia orang tua, pendidikan orang tua, pekerjaan orang tua, pendapatan keluarga, besar keluarga), peer group (karakteristik dan keterikatan) karakter (hormat santun, empati) dan perilaku bullying (peran pelaku dan bentuk bullying). Pengukuran karakteristik dan keterikatan peer group dalam penelitian ini merupakan modifikasi dari kuesioner milik Ramayanti (2000) dengan nilai Cronbach's alpha sebesar 0,882 . Sementara pengukuran karakter hormat dan santun serta empati disusun berdasarkan konsep-konsep yang digunakan dalam penelitian ini dengan nilai Cronbach's alpha sebesar 0,742 . Pengukuran perilaku bullying 
menggunakan kuesioner penelitian Sujiwo (2008) yang merupakan modifikasi dari kuesioner Duffy (2004) dengan nilai Cronbach's alpha sebesar 0,700 .

Pengolahan data dalam penelitian ini dilakukan melalui proses edit, pemberian kode, pemberian skor, pemasukan data ke program, perapihan data, dan terakhir dilakukan analisis data dengan menggunakan program komputer yang sesuai. Data disajikan dalam bentuk tabel dan dianalisis secara deskriptif (rata-rata dan standar deviasi) serta inferensia (uji beda dan korelasi). Analisis data ditampilkan dalam bentuk tabel atau grafik dan sistem skoring dibuat konsisten yaitu semakin tinggi skor maka semakin tinggi kategorinya.

Data karakteristik remaja terdiri atas usia dan jenis kelamin, sedangkan karakteristik keluarga meliputi usia orang tua, pendidikan orang tua, pekerjaan orang tua, pendapatan keluarga dan besar keluarga. Pendapatan keluarga diukur dengan menggunakan skala interval: (1) S Rp1.000.000; (2) Rp1.000.001 Rp2.000.000; (3) Rp2.000.001 - Rp3.000.001; (4) Rp3.000.001 - Rp4.000.000; (5) $\geq$ Rp4.000.001. Menurut BKKBN, besar keluarga dikategorikan menurut jumlah anggota keluarga, yaitu keluarga kecil jika anggota keluarga kurang dari atau sama dengan 4 orang, keluarga sedang jika jumlah anggota keluarga 5 hingga 7 orang, dan keluarga besar jika jumlah anggota keluarga lebih dari atau sama dengan 8 orang. Karakteristik contoh, keluarga contoh, peer group, karakter, dan perilaku bullying dianalisis secara deskriptif, dengan menggunakan angka rata-rata dan uji beda independent sample t-test, serta ditampilkan dalam bentuk tabel atau grafik. Uji korelasi Spearman digunakan untuk menganalisis hubungan antara keterikatan dengan peer group, karakter dan perilaku bullying pada contoh. Selain itu, dilakukan juga uji hubungan juga dilakukan antara karakter dengan perilaku bullying.

\section{HASIL}

\section{Karakteristik Remaja dan Keluarga}

Karakteristik remaja dalam penelitian ini meliputi usia dan jenis kelamin, sedangkan karakteristik keluarga terdiri atas usia orang tua, pendidikan orang tua, pekerjaan orang tua, pendapatan keluarga dan besar keluarga. Hasil penelitian menunjukkan bahwa rata-rata usia remaja laki-laki lebih tinggi daripada perempuan, dan rata-rata usia remaja di SMK Swasta lebih tinggi daripada di SMK Negeri.
Usia orang tua remaja berada pada kategori usia dewasa madya (41-65 tahun). Selain itu diketahui juga rata-rata remaja contoh berasal dari keluarga berukuran sedang. Hasil juga menunjukkan remaja laki-laki memiliki ayah $(52,1 \%)$ dan ibu $(40,0 \%)$ dengan pendidikan akhir SMA/sederajat. Sementara persentase terbesar pekerjaan ayah $(31,2 \%)$ adalah pegawai swasta dan ibu sebagai ibu rumah tangga $(80,0 \%)$. Selain itu diketahui pula pendapatan keluarga mereka $(40,0 \%)$ kurang dari Rp1.000.000. Pada remaja perempuan, diketahui 52,1 persen ayah dan 35,4 persen ibu berpendidikan akhir SMA/sederajat. Persentase terbesar dari pekerjaan ayah $(34,0 \%)$ adalah wiraswasta dan ibu $(85,4 \%)$ adalah ibu rumah tangga. Sementara itu, untuk pendapatan keluarganya $(38,0 \%)$ berada pada kisaran Rp1.000.001-Rp2.000.000.

Berdasarkan perbandingan asal sekolah, diketahui bahwa remaja di SMK Negeri memiliki ayah $(60,0 \%)$ dan ibu $(52,0 \%)$ yang berpendidikan akhir SMA/sederajat. Persentase terbesar pekerjaan ayah mereka $(36,0 \%)$ adalah pegawai swasta dan ibu $(72,0 \%)$ sebagai ibu rumah tangga. Sementara untuk pendapatan keluarga $(46,0 \%)$ diketahui berada pada kisaran Rp2.000.001-Rp3.000.000. Pada SMK Swasta ditemukan persentase terbesar pendidikan ayah $(38,0 \%)$ adalah SMA/ sederajat, sedangkan untuk pendidikan akhir ibu didapatkan hasil yang sama $(30,0 \%)$ antara SD/sederajat dan SMP/sederajat. Persentase pekerjaan ayah $(32,0 \%)$ adalah wiraswasta dan ibu $(90 \%)$ adalah ibu rumah tangga. Selain itu, diketahui juga pendapatan keluarga mereka $(60 \%)$ kurang dari Rp1.000.000. Hasil uji beda menunjukkan bahwa terdapat perbedaan pendapatan keluarga yang sangat nyata $(p<0,01)$ antara siswa SMK Swasta dan Negeri.

\section{Peer Group}

\section{Karakteristik Peer Group Remaja.} Kelompok remaja perempuan (62,0\%) cenderung memiliki anggota kelompok yang usianya sama dan terdiri atas jenis kelamin yang sama dibandingkan remaja laki-laki $(54,0 \%)$ yang memiliki anggota kelompok lebih bervariasi. Hal tersebut menunjukkan bahwa pertemanan remaja laki-laki lebih terbuka daripada perempuan. Sementara itu, remaja laki-laki (52,0\%) lebih banyak yang tidak memiliki atribut khusus dalam kelompoknya daripada perempuan $(44,0 \%)$ dan remaja perempuan $(84,0 \%)$ lebih banyak yang menyatakan tidak memiliki pemimpin dalam kelompoknya daripada laki-laki $(74,0 \%)$. Selain itu, remaja perempuan $(50,0 \%)$ juga lebih banyak yang memilih berkumpul untuk sekedar 
mengobrol, sedangkan remaja laki-laki selain berkumpul untuk mengobrol $(44,0 \%)$ juga suka melakukan olahraga bersama kelompoknya $(44,0 \%)$.

Berdasarkan asal sekolah, remaja pada kedua sekolah menunjukkan hasil yang sama pada pernyataan bahwa usia dari anggota kelompok mereka adalah sama. Remaja di SMK Negeri lebih banyak yang menyatakan bahwa anggota kelompok mereka hanya terdiri atas jenis kelamin yang sama $(58,0 \%)$, tidak memiliki atribut khusus dalam kelompok $(80, \%)$, dan tidak memiliki pemimpin kelompok $(88,0 \%)$ daripada remaja SMK Swasta. Sementara itu, remaja di SMK Negeri (44,0\%) lebih sedikit yang menyatakan bahwa kegiatan mereka dengan peer group hanya sekedar berkumpul daripada remaja di SMK Swasta $(50,0 \%)$.

Hasil penelitian juga menemukan bahwa terdapat perbedaan nyata $(p<0,01)$ antara frekuensi pertemuan remaja laki-laki dan perempuan, dimana frekuensi pertemuan remaja perempuan dengan peer group lebih sering daripada remaja laki-laki. Remaja perempuan menyatakan bahwa pertemuan dengan peer group-nya berkisar antara 5-7 hari dalam seminggu, sedangkan remaja laki-laki berkisar antara 3-4 hari dalam seminggu. Selain itu, diketahui pula bahwa remaja laki-laki lebih sering melakukan pertemuan di malam hari dengan peer group-nya daripada remaja perempuan dengan variasi lama pertemuan antara 1-8 jam sehari. Berdasarkan asal sekolah, tidak terdapat perbedaan nyata pada frekuensi pertemuan remaja, namun perbedaan nyata $(p<0,05)$ ditemukan pada lamanya pertemuan dengan peer group di malam hari. Remaja di SMK Swasta lebih sering bertemu dengan peer group-nya di malam hari dibandingkan remaja di SMK Negeri.

Keterikatan dengan Peer Group. Berdasarkan kategori keterikatan, hampir tiga perlima remaja laki-laki $(56,0 \%)$ berada pada kategori sedang, dan hampir tiga perlima remaja perempuan $(58,0 \%)$ berada pada kategori rendah. Hasil uji beda menunjukkan tidak terdapat perbedaan yang nyata $(p>0,1)$ antara remaja laki-laki dan perempuan dalam keterikatan dengan peer group. Berdasarkan asal sekolahnya, lebih dari separuh remaja di SMK Negeri $(58,0 \%)$ berada pada kategori rendah dan lebih dari separuh remaja di SMK Swasta $(54,0 \%)$ berada pada kategori keterikatan sedang. Hasil uji beda menunjukkan adanya perbedaan nyata $(p<0,05)$ pada keterikatan dengan peer group antara siswa di SMK Negeri dan SMK Swasta (Tabel 1).
Tabel 1 Sebaran remaja berdasarkan kategori keterikatan dengan peer group, jenis kelamin dan asal sekolah, serta nilai rata-rata, standar deviasi, dan koefisien uji beda

\begin{tabular}{|c|c|c|c|c|}
\hline \multirow{2}{*}{$\begin{array}{c}\text { Kategori } \\
\text { keterikatan }\end{array}$} & \multicolumn{2}{|c|}{ Jenis Kelamin } & \multicolumn{2}{|c|}{ Asal sekolah } \\
\hline & $L$ & $\mathrm{P}$ & $\mathrm{N}$ & $\mathrm{S}$ \\
\hline $\begin{array}{l}\text { Tinggi } \\
(>66,67 \%)\end{array}$ & 0,0 & 2,0 & 0,0 & 0,0 \\
\hline $\begin{array}{l}\text { Sedang } \\
(33,33- \\
66,67 \%)\end{array}$ & 56,0 & 40,0 & 42,0 & 54,0 \\
\hline $\begin{array}{l}\text { Rendah } \\
(<33,33 \%)\end{array}$ & 44,0 & 58,0 & 58,0 & 44,0 \\
\hline Total & 100,0 & 100,0 & 100,0 & 100,0 \\
\hline $\begin{array}{l}\text { Rata- } \\
\text { rata } \pm \text { std } \\
\text { (\%skor) }\end{array}$ & $\begin{array}{l}31,7 \pm \\
13,43\end{array}$ & $\begin{array}{r}30,13 \pm \\
14,50\end{array}$ & $\begin{array}{l}27,7 \pm \\
13,81\end{array}$ & $\begin{array}{r}34,17 \pm \\
13,42\end{array}$ \\
\hline $\begin{array}{l}p \text {-value } \\
\text { t-test }\end{array}$ & & 0,562 & & $0,020^{* *}$ \\
\hline
\end{tabular}

Keterangan:

L: Laki-laki, P: Perempuan;

N: SMK Negeri, S: SMK Swasta

${ }^{* *}=$ signifikan pada selang kepercayaan $95 \%$

\section{Perilaku Bullying}

Peran Pelaku Bullying. Hasil penelitian menunjukkan bahwa lebih dari tiga perlima remaja laki-laki $(66,0 \%)$ dan sebagian besar remaja perempuan $(86,0 \%)$ merupakan seorang bully (pelaku langsung bullying). Sementara 22,0 persen remaja laki-laki dan 8,0 persen perempuan merupakan pelaku assisting the bully (menemani temannya melakukan bullying). Selain itu diketahui pula 12,0 persen remaja laki-laki dan 6,0 persen remaja perempuan yang merupakan pelaku reinforcing the bully (mendukung temannya melakukan bullying). Hasil uji beda menunjukkan perbedaan yang nyata $(p<0,05)$ pada peran pelaku bullying antara remaja perempuan dan laki-laki.

Berdasarkan asal sekolah, delapan dari sepuluh remaja di SMK Negeri $(80,0 \%)$ dan sekitar tujuh dari sepuluh remaja di SMK Swasta (72,0\%) merupakan bully (pelaku langsung bullying). Sementara 10,0 persen remaja di SMK Negeri dan 20,0 persen remaja di SMK Swasta adalah pelaku assisting the bully (menemani temannya melakukan bullying). Selain itu, ditemukan pula 10,0 persen remaja di SMK Negeri dan 8,0 persen remaja di SMK Swasta yang merupakan pelaku reinforcing the bully (mendukung temannya melakukan bullying). Hasil uji beda tidak menunjukkan adanya perbedaan $(p>0,1)$ peran pelaku bullying remaja pada kedua kelompok sekolah (Tabel 2). 
Tabel 2 Sebaran remaja berdasarkan peran pelaku bullying, jenis kelamin dan asal sekolah, serta koefisien uji beda

\begin{tabular}{|c|c|c|c|c|}
\hline \multirow{2}{*}{$\begin{array}{l}\text { Peran pelaku } \\
\text { bullying }\end{array}$} & \multicolumn{2}{|c|}{ Jenis Kelamin } & \multicolumn{2}{|c|}{ Asal sekolah } \\
\hline & $\mathrm{L}$ & $\mathrm{P}$ & $\mathrm{N}$ & $S$ \\
\hline Bully & 66,0 & 86,0 & 80,0 & 72,0 \\
\hline $\begin{array}{l}\text { Assisting the } \\
\text { bully }\end{array}$ & 22,0 & 8,0 & 10,0 & 20,0 \\
\hline $\begin{array}{l}\text { Reinforcing } \\
\text { the bully }\end{array}$ & 12,0 & 6,0 & 10,0 & 8,0 \\
\hline Total & 100,0 & 100,0 & 100,0 & 100,0 \\
\hline$p$-value $t$-test & & $0,040^{* *}$ & & 0,640 \\
\hline $\begin{array}{l}\text { Keterangan: } \\
\text { L: Laki-laki, P: } \\
\text { N: SMK Negeri, } \\
* * \text { = signifikan }\end{array}$ & MK S & ta & & \\
\hline
\end{tabular}

Bentuk Bullying. Ada tiga bentuk bullying yang diteliti dalam penelitian ini yaitu bullying fisik, bullying verbal, dan bullying nonverbal. Hasil penelitian menunjukkan bahwa persentase terbesar bentuk bullying yang dilakukan oleh remaja berjenis kelamin laki-laki $(36,4 \%)$ adalah bullying fisik. Sementara itu, remaja berjenis kelamin perempuan cenderung melakukan bullying dalam bentuk verbal $(44,2 \%)$. Berdasarkan asal sekolah, hasil penelitian menunjukkan bahwa persentase terbesar bentuk bullying yang dilakukan oleh remaja yang bersekolah di SMK Negeri $(47,5 \%)$ adalah bullying verbal. Sementara itu, bentuk bullying yang dilakukan oleh persentase terbesar remaja yang bersekolah di SMK Swasta $(33,3 \%)$ adalah bullying fisik dan verbal. Sebaran pelaku bully menurut bentuk bullying, jenis kelamin, dan asal sekolah disajikan pada Tabel 3.

Tabel 3 Sebaran pelaku bully menurut bentuk bullying, jenis kelamin, dan asal sekolah

\begin{tabular}{lrrrr}
\hline \multirow{2}{*}{$\begin{array}{l}\text { Bentuk } \\
\text { bullying }\end{array}$} & \multicolumn{2}{c}{ Jenis kelamin } & \multicolumn{2}{c}{ Asal sekolah } \\
\cline { 2 - 5 } Fisik & 36,4 & 18,6 & 20,0 & 33,3 \\
Verbal & 36,4 & 44,2 & 47,5 & 33,3 \\
Nonverbal & 9,1 & 11,6 & 12,5 & 8,3 \\
$\begin{array}{l}\text { Fisik \& } \\
\text { verbal }\end{array}$ & 18,2 & 18,6 & 15,0 & 22,2 \\
$\begin{array}{l}\text { Verbal \& } \\
\text { nonverbal }\end{array}$ & 0,0 & 4,7 & 5,0 & 0,0 \\
$\begin{array}{l}\text { Fisik, } \\
\text { verbal, \& } \\
\text { nonverbal }\end{array}$ & 0,0 & 2,3 & 0,0 & 2,8 \\
\hline $\begin{array}{l}\text { Total } \\
\text { Keterangan: }\end{array}$ & 100,0 & 100,0 & 100,0 & 100,0 \\
$\begin{array}{l}\text { L: Laki-laki, P: Perempuan; } \\
\text { N: SMK Negeri, S: SMK Swasta }\end{array}$ & & \\
\end{tabular}

\section{Karakter}

Hormat Santun. Berdasarkan kategori karakter hormat santun, lebih dari tiga perlima remaja laki-laki $(64,0 \%)$ berada pada kategori rendah, sedangkan lebih dari tiga perlima remaja perempuan $(62,0 \%)$ berada pada kategori sedang. Hasil uji beda menunjukkan adanya perbedaan yang nyata $(p<0,05)$ pada hormat santun antara remaja laki-laki dan perempuan. Rata-rata skor persen hormat santun remaja perempuan yang lebih tinggi dari remaja laki-laki yang menandakan bahwa remaja perempuan memiliki sikap hormat santun yang lebih baik daripada remaja lakilaki. Berdasarkan asal sekolahnya, separuh dari remaja di SMK Negeri $(50,0 \%)$ berada pada kategori sedang, sementara lebih dari separuh remaja di SMK Swasta $(52,0 \%)$ berada pada kategori rendah. Hasil uji beda tidak menunjukkan perbedaan yang nyata $(p>0,1)$ diantara kedua sekolah tersebut (Tabel 4).

Empati. Berdasarkan kategori karakter empati, hampir tiga perempat remaja laki-laki $(72 \%)$ dan hampir tiga perlima remaja perempuan $(58 \%)$ berada pada kategori rendah. Berdasarkan asal sekolahnya, lebih dari tiga perlima remaja di SMK Negeri $(62,0 \%)$ dan remaja di SMK Swasta $(68,0 \%)$ berada pada kategori rendah. Hasil uji beda menunjukkan tidak terdapat perbedaan yang nyata $(p>0,1)$ karakter empati baik diantara jenis kelamin maupun kedua sekolah (Tabel 5).

Tabel 4 Sebaran remaja menurut kategori karakter hormat santun, jenis kelamin dan asal sekolah, serta nilai rata-rata, standar deviasi, dan koefisien uji beda

\begin{tabular}{|c|c|c|c|c|}
\hline \multirow{2}{*}{$\begin{array}{l}\text { Kategori } \\
\text { karakter }\end{array}$} & \multicolumn{2}{|c|}{ Jenis kelamin } & \multicolumn{2}{|c|}{ Asal sekolah } \\
\hline & $\mathrm{L}$ & $\mathrm{P}$ & $\mathrm{N}$ & $\mathrm{S}$ \\
\hline $\begin{array}{l}\text { Tinggi } \\
(>80 \%)\end{array}$ & 2,0 & 4,0 & 4,0 & 2,0 \\
\hline $\begin{array}{l}\text { Sedang } \\
(60-80 \%)\end{array}$ & 34,0 & 62,0 & 50,0 & 46,0 \\
\hline $\begin{array}{l}\text { Rendah } \\
(<60 \%)\end{array}$ & 64,0 & 34,0 & 46,0 & 52,0 \\
\hline Total & 100,0 & 100,0 & 100,0 & 100,0 \\
\hline $\begin{array}{l}\text { Rata- } \\
\text { rata } \pm \text { sd } \\
\text { (skor } \\
\text { persen) }\end{array}$ & $\begin{array}{r}57,39 \\
\pm 9,37\end{array}$ & $\begin{array}{r}63,17 \pm \\
9,08\end{array}$ & $\begin{array}{r}60,56 \pm \\
10,75\end{array}$ & $\begin{array}{r}60,00 \pm \\
8,46\end{array}$ \\
\hline $\begin{array}{l}p \text {-value } \\
\text { t-test }\end{array}$ & & $0,002^{* *}$ & & 0,774 \\
\hline $\begin{array}{l}\text { Keterangar } \\
\text { L: Laki-laki } \\
\text { N: SMK Ne } \\
* *=\text { signifik }\end{array}$ & $\begin{array}{l}\text {, S: SN } \\
\text { Jada se }\end{array}$ & $\begin{array}{l}\text { n; } \\
\text { Swasta } \\
\text { g kepero }\end{array}$ & $95 \%$ & \\
\hline
\end{tabular}


Tabel 5 Sebaran remaja berdasarkan kategori karakter empati, jenis kelamin dan asal sekolah serta nilai rata-rata, standar deviasi dan koefisien uji beda

\begin{tabular}{|c|c|c|c|c|}
\hline \multirow{2}{*}{$\begin{array}{l}\text { Kategori } \\
\text { karakter }\end{array}$} & \multicolumn{2}{|c|}{ Jenis kelamin } & \multicolumn{2}{|c|}{ Asal sekolah } \\
\hline & $L$ & $\mathrm{P}$ & $\mathrm{N}$ & $S$ \\
\hline $\begin{array}{l}\text { Tinggi } \\
(>80 \%)\end{array}$ & 2,0 & 0,0 & 2,0 & 0,0 \\
\hline $\begin{array}{l}\text { Sedang } \\
(60- \\
80 \%)\end{array}$ & 26,0 & 42,0 & 36,0 & 32,0 \\
\hline $\begin{array}{l}\text { Rendah } \\
(<60 \%)\end{array}$ & 72,0 & 58,0 & 62,0 & 68,0 \\
\hline Total & 100,0 & 100,0 & 100,0 & 100,0 \\
\hline $\begin{array}{l}\text { Rata- } \\
\text { rata } \pm \text { sd } \\
\text { (skor } \\
\text { persen) }\end{array}$ & $\begin{array}{r}56,58 \pm \\
11,52\end{array}$ & $\begin{array}{r}58,91 \pm \\
7,89\end{array}$ & $\begin{array}{r}58,08 \pm \\
11,62\end{array}$ & $\begin{array}{r}57,41 \pm \\
7,91\end{array}$ \\
\hline $\begin{array}{l}p \text {-value } \\
\text { t-test }\end{array}$ & & 0,240 & & 0,738 \\
\hline $\begin{array}{l}\text { Keteranga } \\
\text { L: Laki-lak } \\
\mathrm{N} \text { : SMK N }\end{array}$ & S. & ta & & \\
\hline
\end{tabular}

\section{Hubungan Antarvariabel}

Hubungan Karakteristik Remaja, Keluarga, dan Peer Group dengan Keterikatan dengan Peer Group, Karakter, dan Peran Pelaku Bullying Remaja. Hasil uji korelasi menunjukkan bahwa pada remaja lakilaki, semakin sering frekuensi pertemuan remaja dengan peer group maka semakin tinggi keterikatan remaja dengan peer group-nya $(r=0,395, \alpha<0,01)$. Selain itu, semakin tinggi usia ibu maka semakin baik karakter hormat santun dari remaja $(r=0,388, \alpha<0,01)$ dan semakin tinggi pendapatan keluarga maka kecenderungan remaja menjadi pelaku assisting the bully semakin rendah $(r=-0,289$, $\alpha<0,05)$. Sementara pada remaja perempuan, semakin sering frekuensi pertemuannya dengan peer group membuat karakter hormat santun remaja menjadi rendah $(r=-0,351$, $\alpha<0,05)$. Selain itu, semakin tinggi usia ibu akan semakin baik karakter empati remaja $(r=0,328$, $\alpha<0,05)$ dan semakin tinggi usia ayah maka kecenderungan remaja menjadi pelaku assisting the bully semakin rendah $(r=-0,287$, $\alpha<0,05)$.

Pada remaja di SMK Negeri, semakin sering frekuensi pertemuan remaja dengan peer groupnya maka semakin tinggi keterikatannya dengan peer group ( $r=0,366$, $\alpha<0,01)$. Selain itu, semakin tinggi usia remaja $(r=-0,324, \quad a<0,05)$ dan usia ibu $(r=-0,341$, $\alpha<0,05)$ dari remaja maka kecenderungan remaja untuk menjadi pelaku assisting the bully semakin rendah. Pada remaja di SMK Swasta, semakin tinggi usia ayah $(r=0,313, \alpha<0,05)$ dan ibu $(r=0,329, \alpha<0,05)$ dari remaja maka karakter empati remaja semakin baik. Sementara itu, semakin tinggi pendidikan ibu $(r=-0,331$, $\alpha<0,05)$ dan semakin tinggi pendapatan keluarga $(r=-0,359, \alpha<0,05)$ dari remaja maka karakter empati remaja semakin rendah $(\alpha<0,05)$. Selain itu, semakin sering pertemuan remaja dengan peer group maka kecenderungan remaja menjadi pelaku bully semakin tinggi $(r=0,301, \alpha<0,05)$.

Hubungan antara Keterikatan dengan Peer Group dengan Peran Pelaku Bullying dan Karakter. Hasil uji korelasi menunjukkan hubungan negatif nyata $(\alpha<0,05)$ antara keterikatan dengan hormat santun pada remaja, serta hubungan sangat nyata $(\alpha<0,01)$ dengan peran assisting the bully dan reinforcing the bully pada remaja laki-laki. Sementara pada remaja perempuan, terdapat hubungan negatif yang sangat nyata $(\alpha<0,01)$ antara keterikatan dengan hormat santun dan empati. Berdasarkan asal sekolah, hasil penelitian menunjukkan bahwa terlihat hubungan yang nyata $(\alpha<0,05)$ antara keterikatan dengan hormat santun pada remaja di SMK Negeri. Sementara di SMK Swasta, keterikatan dengan peer group berhubungan negatif yang sangat nyata $(\alpha<0,01)$ dengan hormat santun dan hubungan negatif nyata $(\alpha<0,05)$ dengan empati remaja. Selain itu, keterikatan juga memiliki hubungan yang nyata $(\alpha<0,05)$ dengan peran pelaku bully dan assisting the bully serta hubungan sangat nyata $(\alpha<0,01)$ dengan peran pelaku reinforcing the bully (Tabel 6). Hal ini menunjukkan bahwa semakin terikat remaja dengan peer group maka kecenderungan melakukan bullying semakin tinggi, sementara kualitas karakter remaja menjadi rendah. Hubungan antara keterikatan dengan peer group dengan peran pelaku bullying dan karakter disajikan pada Tabel 6.

Tabel 6 Hasil uji korelasi keterikatan dengan peer group dengan karakter dan peran pelaku bullying

$\begin{array}{lllll}1 & 2 & 3 & 4 & 5\end{array}$

Keterikatan dengan peer group

\begin{tabular}{lrrrrr}
$\mathrm{L}$ & $0,403^{* *}$ & $-0,030$ & 0,193 & $0,413^{* *}$ & $0,401^{* *}$ \\
$\mathrm{P}$ & - & - & 0,118 & 0,145 & 0,278 \\
$\mathrm{~N}$ & $-0,460^{* *}$ & $0,452^{* *}$ & 0,118 & & \\
$\mathrm{~S}$ & $-0,343^{*}$ & $-0,174$ & 0,033 & 0,093 & 0,262 \\
\hline & $0,547^{* *}$ & $-0,309^{*}$ & $0,304^{*}$ & $0,394^{*}$ & $0,442^{* *}$
\end{tabular}

Keterangan:

1: hormat santun, 2: empati, 3: bullying, 4: assisting the bully, dan 5: reinforcing the bully

L: laki-laki, P: perempuan; N: SMK Negeri, S: SMK Swasta

* Signifikan pada $\alpha=0,05,{ }^{* *}$ Signifikan pada $\alpha=0,01$ 
Tabel 7 Hasil uji korelasi hormat santun dengan peran pelaku bullying

\begin{tabular}{llrrr}
\hline \multicolumn{2}{c}{ Variabel } & \multicolumn{1}{c}{ Bully } & \multicolumn{1}{c}{ Assist } & Reinforce \\
\hline \multirow{3}{*}{ Hormat } & L & $-0,213$ & $-0,272$ & $-0,302^{*}$ \\
Santun & P & $-0,175$ & $-0,311^{*}$ & $-0,377^{* *}$ \\
& N & $-0,054$ & $-0,246$ & $-0,261$ \\
& S & $-0,332^{*}$ & $-0,366^{* *}$ & $-0,414^{* *}$
\end{tabular}

Keterangan:

L: laki-laki, P: perempuan; N: SMK Negeri, S: SMK Swasta

* Signifikan pada $\alpha=0,05,{ }^{* \star}$ Signifikan pada $\alpha=0,01$

Hubungan antara Karakter Hormat Santun dengan Peran Pelaku Bullying. Hasil uji korelasi menunjukkan hubungan negatif yang nyata $(\alpha<0,05)$ antara hormat santun dengan peran pelaku assisting the bully dan hubungan negatif yang sangat nyata $(\alpha<0,01)$ dengan peran pelaku reinforcing the bully pada remaja perempuan. Sementara berdasarkan asal sekolahnya, terlihat hubungan negatif yang nyata $(\alpha<0,05)$ antara hormat santun dengan peran pelaku bully dan hubungan negatif yang sangat nyata $(\alpha<0,01)$ dengan peran pelaku assisting the bully dan reinforcing the bully di SMK Swasta. Artinya, semakin tinggi karakter hormat santun remaja maka kecenderungan mereka melakukan bullying menjadi rendah. Hubungan antara karakter hormat santun dan peran pelaku bullying disajikan pada Tabel 7 .

Hubungan antara Karakter Empati dan Peran Pelaku Bullying. Hasil uji korelasi menunjukkan adanya hubungan negatif sangat nyata $(\alpha<0,01)$ antara empati dengan peran pelaku assisting the bully pada remaja perempuan, sedangkan berdasarkan asal sekolah terlihat adanya hubungan negatif nyata $(\alpha<0,05)$ antara empati dengan peran pelaku bully pada SMK Negeri dan peran assisting the bully pada remaja di SMK Swasta. Artinya, semakin tinggi empati remaja maka kecenderungan mereka melakukan bully menjadi rendah. Hubungan antara karakter empati dan peran pelaku bullying disajikan pada Tabel 8.

Tabel 8 Hasil uji korelasi empati dengan peran pelaku bullying

\begin{tabular}{rrrrr}
\hline \multicolumn{2}{c}{ Variabel } & \multicolumn{1}{c}{ Bully } & \multicolumn{1}{c}{ Assist } & Reinforce \\
\hline \multirow{6}{*}{ Empati } & L & $-0,142$ & $-0,062$ & $-0,097$ \\
& $\mathrm{P}$ & $-0,214$ & $-0,417^{* *}$ & $-0,249$ \\
& $\mathrm{~N}$ & $-0,306^{*}$ & $-0,139$ & $-0,145$ \\
& $\mathrm{~S}$ & $-0,013$ & $-0,321^{*}$ & $-0,165$ \\
\hline
\end{tabular}

Keterangan:

L: laki-laki, P: perempuan; N: SMK Negeri, S: SMK Swasta

* Signifikan pada $\alpha=0,05$, ** Signifikan pada $\alpha=0,01$

\section{PEMBAHASAN}

Hasil penelitian ini menemukan bahwa secara umum remaja yang sudah memasuki periode remaja akhir (late adolescence) memiliki keterikatan dengan peer group yang tergolong pada kelompok sedang dan rendah. Hal ini senada dengan Baron dan Byrne (2005) serta Santrock (2007) yang menyatakan bahwa keterikatan remaja dengan peer group paling kuat terjadi pada masa usia remaja awal dan akan menurun pada saat mereka beranjak ke usia remaja akhir. Sementara itu, bila dilihat dari karakteristik peer group yang diikuti remaja, terlihat bahwa remaja laki-laki memiliki peer group yang lebih bervariasi keanggotaannya dibandingkan remaja perempuan. Hal ini terlihat dari beragamnya usia dan jenis kelamin anggota kelompoknya.

Analisis mengenai karakter remaja menunjukkan tidak ada perbedaan yang nyata antara remaja laki-laki dan perempuan dalam hal empati. Meskipun tidak berbeda nyata, skor persentase empati remaja perempuan lebih tinggi dibandingkan remaja laki-laki. Goleman (2009) menyebutkan ketepatan empati merupakan kecakapan paling esensial dari kemampuan sosial, mengindikasikan perempuan cenderung lebih baik dalam dimensi empati daripada laki-laki. Sementara itu, karakter hormat santun menunjukkan perbedaan yang nyata antara remaja laki-laki dan perempuan, dimana hormat santun perempuan lebih tinggi dibandingkan laki-laki. Hasil yang didapatkan ini sejalan dengan penelitian Hastuti (2006) dimana jenis kelamin mempengaruhi terbentuknya karakter anak dan anak perempuan secara umum memiliki karakter yang lebih baik daripada laki-laki.

Hasil identifikasi peran pelaku bullying, ditemukan bahwa peran yang paling banyak dilakukan oleh remaja adalah sebagai bully (pelaku bullying). Hal tersebut berbeda dengan penelitian Nurhuda (2008) dan Saputri (2010) yang menemukan peran pelaku terbanyak pada remaja adalah assisting the bully (menemani temannya melakukan bullying). Selain itu, penelitian ini juga menemukan bahwa remaja perempuan lebih memiliki kecenderungan menjadi pelaku bullying daripada remaja lakilaki. Hal ini juga tidak sama dengan penelitian Nurhuda (2008) yang menemukan bahwa baik laki-laki maupun perempuan memiliki proporsi yang seimbang dalam peran sebagai bully. Penelitian ini juga menunjukkan bahwa remaja perempuan cenderung melakukan bullying verbal dan remaja laki-laki cenderung melakukan bullying fisik. Hal ini sejalan dengan 
penelitian Olweus (2003), Nurhuda (2008) dan Saputri (2010) yang menyatakan bahwa lakilaki lebih banyak melakukan bullying fisik dan perempuan lebih banyak melakukan bullying verbal serta nonverbal.

Selain melihat perbandingan berdasarkan jenis kelamin, dilakukan juga perbandingan menurut asal sekolah remaja. Remaja di SMK Negeri ternyata lebih banyak yang menjadi bully (pelaku bullying) daripada remaja di SMK Swasta dan bentuk bullying yang banyak dilakukan adalah bullying verbal. Sementara bentuk bullying yang sering dilakukan remaja dengan latar belakang SMK Swasta adalah fisik dan verbal (proporsi sama). Penemuan ini menunjukkan bahwa baik siswa SMK Negeri maupun swasta sama-sama beresiko melakukan bullying. Perbedaan latar belakang keluarga yang heterogen dari siswa di SMK Negeri dapat menjadi satu pemicu terjadinya saling ejek diantara remaja. Swearer dan Doll (2001) mengatakan bahwa saat remaja berinteraksi dengan teman-temannya, mereka dapat menoleransi julukan kasar, saling dorong, dan penghinaan verbal yang tidak akan mereka toleransi jika dilakukan oleh orang di luar peer group mereka. Sementara di SMK Swasta, terjadinya bullying dapat terjadi karena latar belakang dari sekolah itu sendiri.

Hasil uji korelasi menunjukkan bahwa keterikatan dengan peer group memiliki hubungan negatif signifikan dengan karakter dan berhubungan positif signifikan dengan perilaku bullying. Hal tersebut terlihat pada kelompok remaja laki-laki dan kelompok remaja di SMK Swasta yang memiliki keterikatan dengan peer group lebih tinggi. Sementara pada kelompok remaja perempuan dan kelompok remaja di SMK Negeri yang keterikatan dengan peer group-nya rendah menunjukkan bahwa keterikatan dengan peer group dapat mempengaruhi kualitas karakter. Penelitian Garnier dan Stein (2001) terhadap remaja usia 18 tahun, juga menemukan bahwa peer group memiliki pengaruh nyata terhadap penggunaan narkoba dan kenakalan pada remaja. Ini mengindikasikan bahwa keterikatan remaja dengan peer group yang terlalu kuat dapat kurang mendukung untuk meningkatkan potensi karakter pada diri remaja dan justru mendukung dalam hal-hal yang buruk seperti perilaku bullying. Besarnya peranan peer group dalam kehidupan remaja disebabkan oleh kebutuhan dari remaja untuk disukai oleh teman-temannya dan ini membuat kebanyakan dari mereka akan melakukan apapun yang dapat membuat mereka diterima oleh kelompok (Santrock, 2007).
Karakter hormat santun pada remaja terlihat tidak memiliki hubungan signifikan dengan peran sebagai bully, kecuali pada SMK Swasta. Hasil juga menunjukkan bahwa remaja perempuan yang memiliki rata-rata hormat santun lebih tinggi justru lebih banyak yang menjadi pelaku bully. Hasil analisis pada jawaban pernyataan siswa perempuan terlihat bahwa hormat santun yang cenderung tinggi di sini adalah hormat santun pada orang lain atau yang lebih tua dari mereka, sedangkan hormat santun pada sesama mereka cenderung rendah. Hasil yang sama juga didapatkan antara karakter empati dengan peran bully, dimana tidak terlihat adanya hubungan yang signifikan kecuali pada remaja di SMK Negeri. Rasa empati remaja timbul saat melihat penderitaan orang lain, namun mereka cenderung menganggap hal seperti memberikan nama yang buruk pada orang lain adalah hal yang biasa dalam hubungan pertemanan dan tidak akan menimbulkan penderitaan bagi orang tersebut. Menariknya, penelitian ini menemukan bahwa remaja lakilaki yang berasal dari keluarga yang berpendapatan lebih rendah cenderung berhubungan dengan meningkatnya skor perilaku assisting the bully. Hal ini kemungkinan dapat terjadi karena remaja laki-laki dari keluarga berpendapatan rendah melakukan assisting the bully agar dapat diterima oleh kelompoknya.

Pengakuan perilaku kebaikan dan keburukan dari remaja memperlihatkan bahwa remaja telah dapat membedakan hal yang baik dan buruk, yang menurut Lickona (1991) remaja telah sampai pada kesadaran moral (moral knowing). Namun melihat banyaknya remaja yang menjadi pelaku bullying dan masih sangat sedikit remaja yang berada pada kategori tinggi dalam karakter menunjukkan bahwa remaja belum sampai pada tahap moral feeling dan moral action, yang mana jika mereka sudah merasakan keinginan untuk melakukan hal yang baik maka mereka akan selalu melakukan hal tersebut.

Hasil juga menunjukkan bahwa usia orang tua mempengaruhi kualitas karakter dari remaja, dimana semakin tinggi usia orang tua maka karakter remaja semakin baik. Usia orang tua yang lebih tinggi menandakan tingkat kedewasaan yang lebih tinggi, sehingga dapat lebih baik dalam menanamkan karakter pada anaknya. Namun, hal yang menarik dari penelitian ini adalah kecenderungan bahwa pendidikan ibu dan pendapatan keluarga remaja yang semakin tinggi justru membuat empati remaja menjadi semakin rendah, 
meskipun secara statistik penelitian ini tidak menemukan adanya hubungan yang nyata. Hal ini dapat terjadi karena remaja dengan kondisi sosial ekonomi yang tinggi terbiasa untuk tercukupi segala kebutuhannya, sehingga mereka kurang memiliki kesadaran sosial terhadap lingkungan disekitarnya.

Karakteristik dari remaja sendiri juga merupakan faktor yang tidak bisa diabaikan begitu saja. Sebagai manusia yang terus tumbuh dan berkembang, perilaku remaja tidak selalu hanya dipengaruhi oleh lingkungan eksternalnya saja, namun mereka memiliki pemikiran dan kepribadian sendiri. Berdasarkan hasil yang ada, tampak bahwa peer group memiliki peranan yang lebih kuat terhadap remaja dibandingkan faktor keluarga dan karakteristik remaja itu sendiri. Namun, Baron dan Byern (2005) mengungkapkan meskipun pengaruh dari peer group sangat kuat dalam kehidupan remaja namun remaja memiliki keinginan untuk mempertahankan otoritas atas diri mereka sendiri. Jenis kelamin juga berpengaruh pada karakter dan perilaku seseorang. Laki-laki dan perempuan memiliki perbedaan dalam memahami, menyikapi dan melakukan suatu hal mengingat keduanya memiliki karakteristik yang juga berbeda. Namun, manusia adalah makhluk yang selalu berkembang sesuai dengan usianya. Usia remaja adalah usia peralihan menuju kedewasaan, yang artinya remaja telah mulai mampu berpikir dan bertindak secara mandiri. Santrock (2007) menyatakan bahwa di usia remaja akhir, remaja mulai mengembangkan gaya keputusan yang lebih mandiri dari pengaruh peer group dan orang tua.

\section{SIMPULAN DAN SARAN}

Penelitian ini menemukan bahwa pendapatan keluarga antara remaja di SMK Negeri dan swasta berbeda nyata. Dalam hal karakteristik peer group, remaja laki-laki cenderung lebih terbuka daripada peer group yang dimiliki remaja perempuan. Perbedaan yang nyata ditemukan antara dua sekolah dalam keterikatan remaja dengan peer group, dimana keterikatan remaja di SMK Swasta lebih tinggi daripada remaja di SMK Negeri. Perbedaan yang nyata ditemukan antara remaja laki-laki dan perempuan dalam karakter hormat santun, dimana karakter hormat santun remaja perempuan lebih baik daripada remaja laki-laki. Sementara berdasarkan asal sekolahnya, tidak ditemukan adanya perbedaan yang nyata diantara keduanya. Pada karakter empati, tidak ditemukan adanya perbedaan yang nyata baik menurut jenis kelamin maupun asal sekolah remaja. Peran pelaku bullying remaja secara umum adalah sebagai bully (pelaku langsung bullying), namun terlihat perbedaan nyata diantara laki-laki dan perempuan, dimana remaja perempuan lebih banyak yang menjadi pelaku bullying daripada remaja laki-laki. Bentuk bullying yang dilakukan remaja laki-laki seimbang antara bullying fisik dan verbal, sedangkan remaja perempuan lebih banyak melakukan bullying verbal. Sementara itu, bentuk bullying yang banyak dilakukan remaja di SMK Negeri adalah bullying verbal dan di SMK Swasta ditemukan hasil yang sama antara bullying fisik dan verbal.

Hasil penelitian menunjukkan bahwa usia orang tua dan pendapatan keluarga memiliki hubungan yang signifikan dengan karakter dan peran pelaku bullying remaja. Keterikatan dengan peer group memiliki hubungan negatif signifikan dengan karakter hormat santun dan empati remaja serta hubungan positif yang signifikan dengan semua jenis perilaku bullying remaja. Selain itu, ditemukan pula hubungan negatif yang signifikan antara karakter hormat santun dan empati dengan perilaku bullying remaja.

Penelitian ini menunjukkan hasil bahwa bullying masih banyak terjadi di kalangan remaja. Namun, banyak di antara mereka yang tidak menyadari bahwa sebenarnya telah atau sedang melakukan tindakan bullying, karena itu perlu dilakukan penyuluhan dan pemahaman tentang bullying kepada para siswa. Pihak sekolah juga diharapkan dapat menciptakan lingkungan sekolah yang aman dan nyaman bagi siswanya, seperti meningkatkan sarana dan prasarana kegiatan siswa dan mengoptimalkan peranan guru BK sebagai sarana konseling bagi para siswa. Lebih dari itu, penanaman karakter seperti hormat dantun dan empati kepada sesama perlu dilakukan sedini mungkin agar mereka tidak akan mau melakukan perbuatan yang dapat menyakiti orang lain. Oleh karena karakter seseorang terbentuk mulai dari dalam keluarga, maka untuk penelitian selanjutnya diharapkan bisa melihat pengaruh keluarga, khususnya gaya pengasuhan orang tua terhadap karakter dan perilaku bullying remaja.

\section{DAFTAR PUSTAKA}

Baron, R. A., \& Byrne, D. (2005). Psikologi Sosial. Djuwita R., penerjemah. Jakarta: Erlangga. Terjemahan dari: Social Psychology, 10th edition. 
Chairani, D. (2005). Gambaran Proses Kelompok pada Sebuah Peer Group Pelaku Bullying di SMA "Z" [Skripsi]. Depok: Fakultas Psikologi. Universitas Indonesia.

Garnier, H. E., \& Stein, J. A. (2001). An 18-Year Model of Family and Peer Effects on Adolescent Drug Use and Delinquency. Journal of Youth and Adolescene, 31, 1.

Goleman, D. (2009). Kecerdasan Emosional. Jakarta: Gramedia.

Hastuti, D. (2006). Analisis Pengaruh Model Pendidikan Prasekolah pada Pembentukan Anak Sehat, Cerdas dan Berkarakter [Disertasi]. Bogor: Sekolah Pascasarjana. Institut Pertanian Bogor.

Lickona, T. (1991). Educating for Character. New York: Bantam Books.

. (2004). Character Matters. New York: Rockefeller Center.

McEachern, Kenny, Blake, \& Aluede. (2005). Bullying in Schools: International Variations. Journal of Social Sciences, 8, 51-58.

Nurhuda, A. (2008). Hubungan Konformitas dan Perilaku Bullying pada Siswa SMA [Skripsi]. Depok: Fakultas Psikologi. Universitas Indonesia.

Olweus. (2003). Bullying. Diambil dari: http://www.olweus.org/public/bullying.page
Puspitawati, H. (2009). Kenakalan Pelajar Dipengaruhi oleh Sistem Sekolah dan Keluarga. Bogor: IPB Press

Ramayanti, N. M. D. (2000). Hubungan Kelompok Sebaya dan Pola Aktivitas dengan Tingkat Kenakalan Remaja di SMK Perguruan Cikini Jakarta Utara [Skripsi]. Bogor: Fakultas Pertanian, Institut Pertanian Bogor.

Santrock, J. W. (2007). Remaja. Widyasinta B, penerjemah; Sallama NI, editor. Jakarta: Erlangga. Terjemahan dari: Adolescene, $11^{\text {th }}$ edition.

Saputri, L. E. (2010). Pengaruh Gaya Pengasuhan Orang Tua dan Kecerdasan Emosional terhadap Perilaku Bullying Remaja Sekolah Menengah Pertama (SMP) [Skripsi]. Bogor: Fakultas Ekologi Manusia, Institut Pertanian Bogor.

[Sejiwa] Semai Jiwa Amini. (2010). Penelitian Mengenai Kekerasan di Sekolah. Diambil dari: http://sejiwa.org/penelitian-mengenaikekerasan-di-sekolah-2008/.

Sujiwo, I. (2008). Hubungan antara Parenting Style Ibu dan Keterlibatan Siswa SMA dalam Perilaku Bullying [skripsi]. Depok: Fakultas Psikologi. Universitas Indonesia.

Swearer, S. M., \& Doll, B. (2001). Bullying in Schools: An Ecological Framework. Journal of Emotional Abuse, 2, 2/3. 